\title{
MÁS ALLÁ DE LOS ALTARES. UN OBISPO DE FELIPE V FRENTE AL RÉGIMEN DE INGRESOS PARROQUIALES EN YUCATÁN, 1715-1728
}

\author{
POR \\ ROdOlFo Aguirre SALVAdOR \\ Universidad Nacional Autónoma de México
}

\section{RESUMEN}

En este artículo se analiza la gestión del obispo de Yucatán, Juan Gómez de Parada, en especial su reforma a los derechos parroquiales, en el marco de un periodo de crítica al clero en el imperio español, y en especial a los religiosos, por parte de la nueva monarquía de Felipe V. Aunque la historiografía sobre la Iglesia de Yucatán ya ha destacado las reformas impulsadas por el obispo Juan Gómez de Parada, sin embargo no se ha profundizado en ellas ni se les ha vinculado a las nuevas políticas eclesiásticas de Felipe V. Sin duda, el gobierno de este obispo estuvo marcado por nuevos vientos reformistas.

PALABRAS CLAVE: derechos parroquiales, pueblos de indios, trabajo indígena, Yucatán

\section{BEYOND THE ALTARS. A BISHOP OF PHILIP V OPPOSITE TO THE REGIME OF PAROCHIAL INCOME IN YUCATAN, 1715-1728}

\begin{abstract}
In this article there is analyzed the management of the bishop of Yucatan, Juan Gómez de Parada, especially his reform to the parochial charges, in the frame of a period of critique to the clergy in the Spanish empire, and especially to the friars, on the part of the new monarchy of Philip V. Though the historiography on the Church of Yucatan already has emphasized the reforms stimulated by the bishop Juan Gómez de Parada, Nevertheless one neither has penetrated into them one nor has linked them to the new ecclesiastic policies of Philip V. Undoubtedly, the government of this bishop was marked by new winds reformists.
\end{abstract}


KEY WORDS: Parochial charges, Indigenous towns, Indigenous work, Yucatan

Recibido/Received 02/02/2011

Aceptado/Accepted 15/04/2011

Aunque no toca inmediatamente al real patronato el gobierno con los eclesiásticos y regulares; debo decir a vuestra excelencia que el remedio de unos y otros consiste en que los prelados sean de aquel cuidadoso celo que conviene, para que corrijan prontamente cualquiera distracción o desorden $[\ldots]^{1}$

[...] siendo obispo, debe escudriñar los males que a su pueblo inficionan para procurar, como pastor, precaver las ovejas de su redil de la contagiosa peste que las infesta, tanto más mortal cuanto menos conocida de los que de ella adolecen, como son los republicanos de aquella provincia $[\ldots]^{2}$

Varios estudios sobre las doctrinas franciscanas de Yucatán se han encargado anteriormente de explicar puntualmente el peso religioso, social y económico que tuvieron a lo largo de la era colonial esas entidades. ${ }^{3}$ Quizá como en ninguna otra diócesis novohispana, en la península yucateca las doctrinas de indios tuvieron una importancia tal, más allá del ámbito eclesiástico, que todos los grupos de poder estuvieron en mayor o menor medida involucrados con su devenir. De ahí que cuando algún obispo intentó promover cambios no sólo los franciscanos reaccionaran sino también los encomenderos, los comerciantes o los funcionarios reales; todos tuvieron algo que decir.

En este trabajo nos centraremos en el periodo del gobierno diocesano de Juan Gómez de Parada por considerar que las reformas que promovió se dieron

1 «Relación del estado de la Nueva España en los ocho años de su gobierno, que hace el duque de Alburquerque al excelentísimo señor duque de Linares su sucesor en los cargos de virrey, gobernador y capitán general de este reino, de que tomó posesión en 27 de noviembre del año de 1702», en: Dos documentos virreinales. Las instrucciones al virrey Luis de Velasco II y las instrucciones y memoria del segundo duque de Alburquerque, compilación y edición de E. DE LA TORRE VILLAR, México, Instituto de Investigaciones Históricas-UNAM, 2010, 83.

2 Juan Francisco de Córdoba, procurador del obispo Gómez de Parada ante la real audiencia de México, 17 de abril de 1723, en: G. Solís RoBlEDA, editora, Contra viento y marea. Documentos sobre las reformas del obispo Juan Gómez de Parada al trabajo indígena, Mérida, Centro de Investigaciones y Estudios Superiores en Antropología Social-Instituto de Cultura de Yucatán-Editorial Pareceres, $2003,97$.

${ }^{3}$ N. M. FARris, La sociedad maya bajo el dominio colonial. La empresa colectiva de la supervivencia, Madrid, Alianza Editorial, 1992; M. C. Garcia Bernal, Yucatán. Población y encomienda bajo los Austrias. Sevilla: Escuela de Estudios Hispano Americanos, 1978; G. Solís RoBlEDA, Entre la tierra y el cielo. Religión y sociedad en los pueblos mayas del Yucatán colonial. México: CIESAS, ICY: Miguel Ángel Porrúa, 2005; BraCAMONTE, La conquista inconclusa de Yucatán. Los mayas de la montaña, 1560-1680. México: CIESAS, Universidad de Quintana Roo: M. A. Porrúa, 2001 y A. RoCHER SALAS, La disputa por las almas. Las órdenes religiosas en Campeche. Siglo XVIII, México, CONACULTA, 2010.

Hispania Sacra, LXIII

128, julio-diciembre 2011, 469-499, ISSN: 0018-215-X 
en condiciones políticas singulares en la metrópoli, luego de la guerra de sucesión. Aunque la historiografía sobre la Iglesia de Yucatán ya ha destacado las reformas impulsadas por el obispo Juan Gómez de Parada y en menor medida la realización de un sínodo diocesano, sin embargo no se ha profundizado en las mismas ni tampoco se les ha vinculado a las nuevas políticas eclesiásticas de Felipe V.

Si bien existen estudios que se han ocupado de las problemáticas alrededor de los derechos parroquiales, generalmente se dedican más a la segunda mitad del siglo XVIII. ${ }^{4}$ Los realizados para Yucatán han establecido bien los vínculos de otros actores extra-eclesiásticos con la generación de ingresos parroquiales, tales como los caciques, los comerciantes o los encomenderos y regidores, pero el gobierno de Gómez de Parada aun espera mayores análisis por su importancia como signo de los nuevos vientos borbónicos.

Por consiguiente, en este artículo se analiza la gestión de ese prelado respecto a la reforma de las obvenciones y los derechos parroquiales, en el contexto de un periodo marcado por una creciente crítica al clero en todo del imperio español, en especial a los regulares, por parte de la nueva dinastía y sus consejeros en Madrid. No obstante que, en el corto plazo Gómez de Parada tuvo que suspender sus reformas, ante el revuelo político causado, y por lo cual la corona decidió destinarlo a otra diócesis, sus reformas fueron retomadas por su sucesor y fueron llevadas a la práctica, con el beneplácito de Madrid. Por su parte, el resistente régimen colonial yucateco tuvo que advertir que la nueva dinastía monárquica tenía políticas diferentes sobre el gobierno de las Indias, particularmente en lo referente a la Iglesia, y que actuaba en consecuencia. En este sentido, la actuación del obispo aquí estudiado encarnó los nuevos vientos políticos venidos de ultramar.

\section{TRABAJO INDÍGENA, ECONOMÍA E IGLESIA EN YUCATÁN}

La península de Yucatán, aunque era parte del virreinato novohispano, sin embargo guardaba una lejanía geopolítica con respecto a las regiones centrales cuyo eje era la ciudad de México. Para el siglo XVIII varios aspectos que ya habían quedado atrás en la mayoría del territorio novohispano, en Yucatán seguían vigentes, especialmente el régimen de encomiendas. Su preservación nos indica que la cuestión indígena se manejaba ahí de manera diferente. En la pe-

\footnotetext{
${ }^{4}$ Por ejemplo, el trabajo de D. A. Brading, Una Iglesia asediada: el obispado de Michoacán, 1749-1810, México, Fondo de Cultura Económica, 1994, 150-169, o el de W. B. TAYLOR, Ministros de lo sagrado. Sacerdotes y fieles en el México del siglo XVIII, México, El Colegio de Michoacán-Secretaría de Gobernación-El Colegio de México, 1999, 2 vols.
} 
nínsula no había minas ni grandes haciendas pues la tierra no era especialmente fértil; Mérida y Valladolid basaron su riqueza en la encomienda y las estancias agrícolas y ganaderas, mientras que Campeche lo hizo con el comercio y las actividades portuarias. ${ }^{5}$ De ahí que su principal riqueza fuera el trabajo indígena, su agricultura, sus manufacturas textiles y los géneros que producían y podían comercializarse.

Desde el punto de vista social, los encomenderos seguían siendo a principios del siglo XVIII el grupo social predominante, no sólo por su riqueza sino también por su ascendencia social y su poder político. La mayoría se concentraba en los alrededores de Mérida y Valladolid, menos en Campeche, y ocupaban las regidurías de los cabildos. Junto a ellos, los funcionarios reales y los comerciantes ejercían el control de la provincia.

\section{División eclesiástica de Yucatán en 1590}

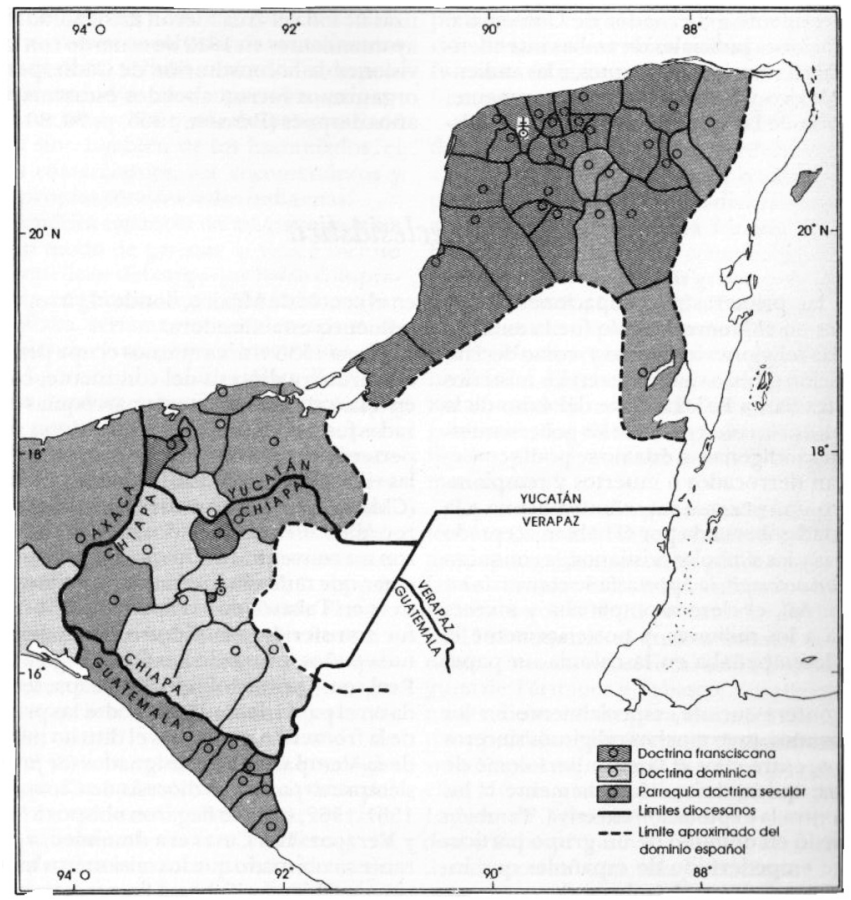

Fuente: Peter Gerhard, La frontera sureste de la Nueva España, México, UNAM, 1991, p. 18

${ }^{5}$ A. ROCHER SALAS, op. cit..41. 
Un mecanismo básico para la apropiación del trabajo indígena por estos grupos eran los repartimientos de trabajadores, controlados por el gobernador, para atender todo tipo de labores: agricultura, ganadería, tareas domésticas y nodrizas, transporte, astillero, marina, pesca, salinas y el corte de palo de Campeche ${ }^{6}$ El bajo costo y la disponibilidad de mano de obra crearon fuertes argumentos a favor de perpetuar el servicio compulsivo de indios, el cual no había cambiado de manera sustancial a principios del siglo XVIII, e incluso se les había unido el factor de la piratería; es decir, puesto que para defender las costas eran muy necesarias las milicias, igualmente se exigía a los pueblos varios servicios de avituallamiento y transporte.

En Yucatán, como en el resto de la Nueva España indígena, se habían desarrollado mecanismos de distribución de mercancías y dinero por adelantado a los indios, conocidos también como repartimientos, que para principios del siglo XVIII estaban plenamente consolidados. ${ }^{7}$ Mediante ellos, los españoles repartían géneros o ganado a precios elevados, que los nativos pagaban en plazos, o bien, dinero para comprar anticipadamente, a precios bajos, sus cosechas o manufacturas.

Esta actividad generaba elevados dividendos al gobernador, a sus funcionarios, a los capitanes de la milicia, a los comerciantes y a los encomenderos. La importancia económica del trabajo forzoso y los repartimientos de mercancías era tal que incluso las instituciones eclesiásticas se beneficiaron de ellos, especialmente el clero parroquial, ya sea mediante el cobro de las obvenciones parroquiales, o bien, mediante su participación directa en los repartimientos de mercancías y dinero. ${ }^{8}$

Desde el siglo XVI, los obispos Toral y Landa habían criticado el trabajo forzado e intentaron suprimirlo, sin lograrlo. A fines del siglo XVII el obispo Juan Cano Sandoval convalidó su existencia, apoyando a los cabildos seculares y al gobernador. De esa forma, a principios del siglo XVIII, todas las controversias que sobre el asunto se habían suscitado en más de siglo y medio habían sido zanjadas a favor de su permanencia.

${ }^{6}$ Ibidem 51.

${ }^{7}$ Margarita Menegus, «La economía indígena y su articulación al mercado en Nueva España. El repartimiento forzoso de mercancías» y Robert W. PATCH, «Cultura, comunidad y «rebelión» en el levantamiento maya de 1761 en Yucatán», en: M. Menegus, El repartimiento forzoso de mercancías en México, Perú y Filipinas, México, Instituto Mora- Centro de Estudios sobre la Universidad, 2000, 965 y 146-170 respectivamente.

${ }^{8}$ En Dzonotpip los géneros que se pagaban al doctrinero eran: mantas de algodón, maíz, chile, miel y frijoles, candelas, cera, hilo, sal, cacao. Auto de absolución del obispo Gómez de Parada a los religiosos de Dzonotpip por pesquisa en visita general, Dzonotpip a 19 de diciembre de 1719, en: J. GómEZ DE PARADA, Constituciones sinodales del obispado de Yucatán, transcripción, edición y notas de G. Solís RobledA, Mérida, Universidad Nacional Autónoma de México, 2008, 282. 
Respecto a la Iglesia, en Yucatán coexistían dos entidades en un plano desigual: la provincia franciscana de San José y la diócesis. La primera, fundada desde $1565,{ }^{9}$ seguía siendo la corporación religiosa más importante y rica para principios del siglo XVIII. Con respecto a los indios, los franciscanos habían sido y eran los principales garantes de su gobierno, habían reducido a indios fugitivos, convertido a rebeldes y pacificado sus motines; por entonces, administraban tres docenas de conventos, con sus respectivas doctrinas, ${ }^{10}$ que atendían a los principales núcleos indígenas. En cada convento-doctrina el guardián o vicario, junto con el doctrinero, ejercían un gran control sobre sus feligreses, mismo que iba más allá de la pura administración espiritual:

Exentar a los indígenas del tributo, exigir los derechos parroquiales en especie o en dinero, hacerlos trabajar para ellos o para terceros, aprobar matrimonios y ser juez con facultad para juzgar y castigar, otorgaron al doctrinero un poder que sobrepasaba incluso al de los representantes del Estado y, por supuesto, al de los caciques y gobernadores indígenas. Los franciscanos consideraron como un derecho inalienable la absoluta potestad que ejercían sobre los indígenas bajo su administración. ${ }^{11}$

El clero secular, en cambio, no tenía la misma presencia que los franciscanos, por más que desde el concilio de Trento y el tercer concilio mexicano de 1585 se concediera un lugar prominente a los obispos como cabezas de la Iglesia novohispana. Antes de la secularización de doctrinas iniciada en 1753, los clérigos tenían a su cargo 40 curatos, principalmente en villas de españoles y en Mérida, aunque también administraban una parte menor de la población indígena.

Además de la curia diocesana, asentada en Mérida, existían cinco vicarios foráneos, con residencia en las principales poblaciones de la península: Valladolid, Petén Itzá, Carmen, Tabasco y Campeche, quienes también fungían como curas. ${ }^{12}$ Esta presencia secundaria del clero secular en Yucatán ${ }^{13}$ quizás haya sido uno de los motivos por el que el obispo Gómez de Parada se dio a la tarea de impulsarlo, aprovechando el poder que el rey le confirió en la década de 1720 .

En lo que sí coincidían tanto franciscanos como clérigos era en defender el cobro indiscriminado de las obvenciones y derechos. La discusión entorno a los ingresos parroquiales en Nueva España comenzó desde el siglo XVI y estuvo enfocada por entonces a definir las fuentes de donde deberían originarse, tema difícil de solucionar.

\footnotetext{
${ }^{9}$ Gerhard, La frontera sureste de la Nueva España, México, UNAM, 1991, 19.

${ }^{10}$ A. Rocher SAlAS, o cit., 62 y 78-79.

11 Ibidem 99.

12 Ibidem 54.

${ }^{13}$ Ibidem 60. En el puerto de Campeche, por ejemplo, a principios del siglo XVIII, no llegaba a 12 el número de clérigos; para mediados del mismo siglo apenas sobrepasaban los 28.
}

Hispania Sacra, LXIII

128, julio-diciembre 2011, 469-499, ISSN: 0018-215-X 
Según el real patronato, la corona tenía la obligación de sustentar a la Iglesia, para lo cual obtuvo de Roma la concesión del diezmo. Sin embargo, este importante recurso se utilizó sobre todo para sustento del alto clero secular, quedando sin resolver el del clero parroquial, el que, a medida que aumentó, necesitó de más recursos materiales.

En el siglo XVI se pidió a los encomenderos mantener a los ministros; mas, con la decadencia de la encomienda en las diócesis centrales novohispanas y el traspaso de los pueblos a la corona, volvió a recaer en el rey la obligación del sustento. Aunque en Yucatán la encomienda siguió vigente hasta el siglo XVIII, los encomenderos pagaban con mucha irregularidad su aportación a la atención espiritual de los indios. ${ }^{14}$

Para solventar en parte esa problemática se decidió que de la real hacienda se pagara un salario a los curas, conocido como sínodo real, cuyo monto fue por entonces de 100 pesos y 50 fanegas de maíz al año. ${ }^{15}$ Aunque esta figura se conservó hasta el siglo XVIII, fue muy irregular y muchos curas y doctrineros, tal vez la mayoría, no gozaron de ese beneficio. ${ }^{16}$ Por ello, se fue imponiendo la idea del pago directo de los fieles a sus ministros, a pesar de los detractores que argumentaron que el cobrar a los indios podía confundirse con una venta de sacramentos, en detrimento de la fe.

Aunque inicialmente se pensó en cobrar más tributo para de ahí pagar a los curas, hubo mucha resistencia de los pueblos. E siguiente paso fue entonces pedir «limosna» por los entierros y matrimonios, no así para las confesiones y los bautismos. Con el tiempo las limosnas se hicieron obligatorias lo cual fue bien visto, tanto por la corona, pues quitaba presión a su real hacienda, como por el alto clero, pues inhibía reclamos por una mayor distribución del diezmo. Las leyes del siglo XVI especificaron que de los fondos de las cajas comunales se pagaran no solo gastos civiles sino también a los ministros espirituales. ${ }^{17}$ Así, los pagos de las obvenciones provenientes de los pueblos se generalizaron, aunque sin un ordenamiento o tasa uniforme.

En el siglo XVII, ante la diversidad de formas de pago y los conflictos entre curas y feligreses se intentó imponer aranceles fijos. En 1638 se elaboró uno en el arzobispado de México, ${ }^{18}$ el cual se convirtió en adelante en un referente

\footnotetext{
14 Petición de los franciscanos y de los curas seculares representando su oposición al arancel de limosnas y obvenciones, México a 15 de noviembre de 1723, en: J. GóMEZ DE PARADA, op. cit. 331. 137.

15 Ch. Gibson, Los aztecas bajo el dominio español, 1519-1810, México, Siglo XXI, 1989, 101-

${ }^{16} \mathrm{Al}$ respecto pueden verse su ausencia en curatos del arzobispado de México en: Archivo General de la Nación, México (en adelante: AGNM) ramo de Bienes Nacionales 218.

${ }^{17}$ Ch. Gibson, op . cit. 218.

18 AGNM Ramo Civil 2141, ex 1, real provisión para que se obedezca el arancel de derechos parroquiales de 1638, en todos los curatos del arzobispado, de 9 de noviembre de 1741 .
} 
para muchos de los conflictos de las décadas siguientes. ${ }^{19}$ En Yucatán, el asunto de los aranceles se abordó también desde el siglo XVI, cuando hubo ya intentos por regularlos, aunque los franciscanos siempre lograron imponer su propia costumbre.

Es probable que un primer sínodo de 1581, presidido por el obispo Gregorio de Montalvo, haya intentado fijar un arancel, mismo que no llegó a aplicarse. En 1697, el obispo fray Antonio de Arriaga escribió al rey sobre su intención de hacer un sínodo diocesano al saber que curas y doctrineros cobraban lo que deseaban a los indios. ${ }^{20}$

En 1701 la corona ordenó al obispo fray Pedro de los Reyes elaborar aranceles aunque tampoco tuvo éxito. Una década después, el mismo prelado reconoció que los indios seguían siendo «presa» de sus curas en el cobro de las obvenciones. ${ }^{21}$ En 1710 el rey insistió en la realización de un sínodo para establecer un arancel que acabara con los abusos. Así, no había constancia de ningún arancel aplicado antes de Gómez de Parada. En 1716, el papa concedió el permiso al obispo para hacer el sínodo y el rey así lo ordenó en cédula de 10 de febrero del mismo año, ${ }^{22}$ aunque nuevamente se pospuso.

$\mathrm{Al}$ problema de fijar tasas fijas de obvenciones y derechos parroquiales, debemos aunar el de las formas de pago de los indios, que podía efectuarse en dinero, géneros o mano de obra. La historiografía señala que, normalmente, los curas preferían los dos últimos y que sólo cuando había cosechas abundantes y los géneros, en especial el maíz, tenían un bajo costo, preferían el dinero.

Hacia la primera mitad del siglo XVIII los derechos parroquiales en Yucatán se dividían en dos grandes rubros: obvenciones mayores y obvenciones menores. Las primeras equivalían a lo que en el arzobispado de México llamaban «pie de altar»; es decir, aquellas cíclicas que cada año se cobraban regularmente, como fiestas titulares, patronales, o procesiones. Las segundas, conocidas como «accidentes» en el centro de Nueva España, estaban constituidas principalmente por el pago de bautismos, casamientos o entierros. Además, los indios debían entregar una limosna semanal en géneros como maíz, mantas de algodón, miel, cera o aves de corral. Pero también contribuían con trabajo personal.

\footnotetext{
19 W. B. TAYLOR, o cit., vol. II, 634. Este autor ha señalado que hasta antes del arancel de 1767, lo que privó fue el acuerdo y no las tasas fijadas por las mitras.

${ }^{20}$ Gabriela Solís RoBlEDA, «Introducción», en: J. GómEZ DE PARADA, op. cit. 9-10.

${ }^{21}$ Ibidem 27.

22 Representación ante la audiencia de México del cabildo de Mérida y abogado de los naturales, sobre los perjuicios que se siguen del sínodo realizado por el obispo Gómez de Parada, de 6 de febrero de 1723, en: J. GómEZ DE PARADA, op. cit., 299.
} 
Lo importante es que no se atendía a ningún arancel preestablecido, sino que cada doctrinero llegaba a un acuerdo con su feligresía, que muchas veces degeneraba en verdaderos abusos. ${ }^{23}$ Así, el pago de las obvenciones no era todo lo que los indios aportaban a sus curas, pues además daban mano de obra para la construcción y mantenimiento de los templos, así como para servicios domésti$\cos { }^{24}$ Fue una práctica común que los curatos y doctrinas atrajeran numerosos cantores, cuyas tareas no se limitaron a las funciones litúrgicas sino a varias otras, como su labor en sembradíos de algodón de los padres, por ejemplo.

La disponibilidad de mano de obra y géneros, bajo la justificante del pago de obvenciones, puso en condiciones a los ministros para participar exitosamente en los repartimientos de mercancías y dinero como el resto de los grupos de poder. De ahí que cuando un nuevo obispo de Yucatán, Juan Gómez de Parada, se propuso un reordenamiento de su cobro y de los servicios personales, se inició una cascada de protestas de ambos cleros que se articularon a otras del gobernador, de los cabildos civiles, de los encomenderos y de los comerciantes por el asunto de la suspensión general de servicios personales. Durante esos años salieron a relucir los entresijos del control indígena y se produjeron fuertes debates sobre la pertinencia o no del cambio impulsado por el obispo, a tal grado que la monarquía tuvo que decidir entre seguir apoyando al prelado, o, en aras de la estabilidad política, permitir la continuidad del régimen.

Gómez de PARAda: entre los Vientos Reformistas DE MADRID Y El STATUS QUO DE YUCATÁN

A principios del siglo XVIII el nuevo gobierno monárquico impulsó la reforma del clero, luego de la ambigua participación de este último en las regiones orientales de la península durante la guerra de sucesión. Una derivación de ello fue la sensibilidad del régimen de Felipe $\mathrm{V}$ a las cuestiones eclesiásticas, tanto en España como en América. 25

Luego de una estancia muy provechosa en España, en donde se graduó de doctor y seguramente buscó en el Consejo de Indias un alto cargo eclesiástico,

${ }^{23}$ A. Rocher SALAS, o cit., 64-65: «Algunos curas exigían las limosnas en moneda o en géneros, según las necesidades del mercado. Así, en épocas de escasez de cera, patíes, maíz, chile y frijoles, pedían el pago en estas especies, con lo que, además de evitar padecer por la carestía de estos productos, realizaban grandes negocios con su venta a precios elevados. En la situación opuesta, es decir, cuando las cosechas habían sido óptimas y los precios se encontraban en picada, fijaban los pagos en moneda».

${ }^{24}$ Ibidem 111.

${ }^{25}$ Rodolfo AgUIRRE, Un clero en transición. Población clerical, cambio parroquial y política eclesiástica en el arzobispado de México, 1700-1749. México, Instituto de Investigaciones sobre la Universidad y la Educación, en prensa, especialmente el capítulo VIII «El designio político de Felipe V: clérigos útiles, frailes sujetos». 
Juan Gómez de Parada fue designado obispo de Yucatán en 1715 y al año siguiente tomó posesión de la mitra, a la edad de 38 años, en plena madurez y fuerzas. ${ }^{26}$ Fue nombrado por Felipe V una vez terminada la guerra de sucesión, en una época de crecientes críticas a la Iglesia española y su relación con Roma, aunadas a una política de fortalecimiento del real patronato.

El novel obispo presenció el ambiente de recelo de la nueva monarquía hacia la Iglesia española, circunstancia que condicionó su actuación en el obispado yucateco con respecto a la transformación de su clero y su feligresía, al grado de cuestionar el régimen político y económico imperante en toda la provincia. Esto nos puede indicar que los obispos nombrados durante y después del conflicto sucesorio eran afectos a las nuevas tendencias regalistas de Felipe $\mathrm{V}$, exacerbadas por el sentimiento de traición achacado al clero de los reinos orientales de Aragón, Valencia y Cataluña, como se ha mencionado antes. ${ }^{27}$

Gómez de Parada llegó a Yucatán en una etapa de transición en la política eclesiástica de la corona, caracterizada por reforzar la autoridad de los obispos en detrimento del poder tradicional de las órdenes religiosas. Esto fue patente en el arzobispado de México en la primera mitad del siglo XVIII, cuando José Lanciego Eguilaz, quien gobernó durante la misma época que Gómez de Parada, pudo extender su jurisdicción a todos los rincones de su diócesis mediante un número sin precedentes de jueces eclesiásticos, gracias en buena medida al apoyo de Madrid. ${ }^{28}$ En la diócesis de Oaxaca, por la misma época, su obispo pudo reorganizar ciertas doctrinas, y desprender de ellas varios curatos para su clerecía, para lo cual contó también con todo el respaldo de la corona. ${ }^{29}$

De Yucatán, particularmente, llegaron a Madrid informes sobre la opresión en que vivían los indios debido a los servicios forzosos controlados por el gobernador, al reparto de mercancías y dinero y a los abusos del clero parroquial, por lo que se buscó solucionarlos de fondo poniendo al frente de la tarea al obispo Gómez de Parada. Este último acometió encargos concretos de Madrid: solucionar la tensión provocada por la secularización de algunas doctrinas franciscanas en 1682, visitar el obispado, averiguar las vejaciones a los indios y encabezar un sínodo diocesano para formular estatutos que ayudasen a corregir los abusos detectados.

\footnotetext{
${ }^{26}$ G. Solís RoBLEDA, editora, Contra viento y marea..., «Introducción», XXVII.

${ }^{27}$ Maximiliano BARRIO GozALO, «El clero bajo sospecha a principios del siglo XVIII. El informe de Macanaz y la respuesta de los obispos», Investigaciones Históricas 22 (2002) 47-62.

${ }^{28}$ Rodolfo AGUIRRE, «El establecimiento de jueces eclesiásticos en las doctrinas de indios. El arzobispado de México en la primera mitad del siglo XVIII», Revista de Historia Crítica julio-diciembre (2008) 14-35.

${ }^{29}$ F. CANTERla y M. DE Tovar, La Iglesia de Oaxaca en el siglo XVIII, Sevilla, Escuela de Estudios Hispanoamericanos, 1982, 23-86.
}

Hispania Sacra, LXIII

128, julio-diciembre 2011, 469-499, ISSN: 0018-215-X 
Gómez de Parada había nacido en una región diferente en varios sentidos a Yucatán: Nueva Galicia, situada en el occidente, zona de frontera con tribus indígenas poco o nada sometidas al régimen español, y en donde para el siglo XVIII predominaba la mano de obra voluntaria en los indios, no había encomiendas y el repartimiento de mercancías era casi nulo.

Podemos imaginar la actitud del prelado cuando visitó su diócesis y presenció un mundo indígena contrastante al que conocía. Así, el nuevo obispo impulsó cambios sustanciales bajo la premisa de que la salvación «eterna» de los indios debía comenzar con su salvación «terrenal», de la cual desprendió una conclusión política arriesgada: el régimen imperante comprometía la fe y la evangelización de los naturales, y por tanto, su salvación espiritual. Ello le costó, a la larga, su estadía en la diócesis.

Gómez de Parada tuvo que enfrentar duras críticas al clero parroquial por parte de los opositores a sus reformas, las cuales no fueron desmentidas sino más bien matizadas por el primero. Uno de los aspectos que más reclamaban a la Iglesia fue la existencia de muchos indios como auxiliares de los curatos, quienes se alejaban de sus obligaciones comunales, en beneficio de los intereses del clero parroquial.

Para los regidores de los cabildos españoles de Yucatán y los funcionarios reales, esta costumbre era una forma de control que sólo beneficiaba a los curas. Sin duda, los llamados «indios de Iglesia» eran una reserva de mano de obra muy cotizada ante la cotidiana pugna que todos los días se libraba por su trabajo.

Los regidores de Valladolid alegaban que esto provocaba la falta del cultivo del maíz y por tanto, afectaciones al común sustento. Sus similares de Campeche se unieron a tales críticas, denunciando excesos en el cobro de los matrimonios y que familiares e indios de Iglesia eran protegidos bajo el pretexto de la inmunidad eclesiástica, quedando exentos de la jurisdicción real. Otro asunto que se criticaba mucho era el pago de las obvenciones en géneros, los cuales eran muy disputados por todos.

Para enfrentar todo ello, Gómez de Parada estuvo dispuesto no sólo a corregir a su Iglesia, sino al régimen de trabajo de los indios de la península en su totalidad, para lo cual pidió a la real audiencia de México una orden para suspender los servicios forzosos que regulaba el gobernador. En la capital novohispana hubo buena acogida al discurso del obispo: el protector fiscal de indios de la audiencia pidió que los curas ayudaran a evitar las extorsiones a los indios, que el alcalde ordinario de Mérida informara sobre esas problemáticas y que el gobernador suspendiera los servicios de trabajo. El fiscal de la misma aceptó las propuestas y, aun más, pidió enviar real provisión al gobernador para suspender los repartimientos, bajo pena de suspensión de oficio. Finalmente, la 
audiencia así lo ordenó. ${ }^{30}$ Este respaldo dio más influjo a Gómez de Parada para fortalecer su autoridad y la de su clero.

El escalamiento del proyecto episcopal puso a la defensiva al resto de poderes de Yucatán, pues todos salían de uno u otro modo afectados, a tal grado que el mismo gobernador, olvidándose de cualquier diplomacia política, encabezó una férrea oposición en contra del prelado. Éste pidió entonces el apoyo de $\mathrm{Fe}$ lipe V para que la provisión pudiera ejecutarse, el cual llegó a fines de 1722, cuando el rey avisó al gobernador que el obispo estaba comisionado para remediar todo lo referido, con total independencia del gobernador y demás justicias: «Y en caso de contravención o resistencia, os suspenda de vuestro empleo y resuma en sí vuestra jurisdicción». ${ }^{31} \mathrm{Al}$ virrey y a la audiencia les ordenaba también dar todo el auxilio necesario. Podemos imaginar el impacto que esta orden causó en el palacio de gobierno de Mérida y en los cabildos de españoles de esa ciudad, de Valladolid y de Campeche.

En marzo de 1723 Gómez de Parada, en su calidad de comisionado real, informó a Madrid que había comenzado a cancelar los servicios de los indios, a pesar de las provocaciones y protestas de los regidores de Mérida. ${ }^{32}$ El palacio episcopal se convirtió en una especie de audiencia provincial en donde todo aquel que quisiera denunciar algún maltrato de las autoridades o de los vecinos, podía acudir.

Gómez de Parada estaba usando ampliamente de su comisión para imponer sus reformas. En tanto, el gobernador, vecinos, encomenderos y regidores, estuvieron muy atentos, al cerciorarse que cada día aumentaba el riesgo de que el sistema de trabajo indígena y los repartimientos de mercancías y dinero de que se beneficiaban se acabaran. El gobernador Antonio de Cortayre presenció como el obispo iba tomando el mando en la provincia y decidió escribir al rey, en julio de 1723, quejándose del ensanchamiento de la autoridad episcopal y la disminución de la real:

[...] padeciendo la pena de estar mirando ejecutar al reverendo obispo las acciones pertenecientes al gobierno y capitanía general, nombrando por ministros de justicia a los doctrineros, ejecutando prisiones de seculares y a los cabos de guerra mandándolos con

${ }^{30}$ Autos de la Real Audiencia sobre los servicios de indios en Yucatán, auto de 30 de abril y cédula al alcalde ordinario de Mérida, 2 de mayo de 1722, en: G. Solís RoBledA (editora),Contra viento y marea..., 22

${ }^{31}$ Despacho del rey al gobernador de Yucatán comunicándole la comisión especial y privativa concedida al obispo Gómez de Parada para que remedie los males por él denunciados, Madrid, 28 de noviembre de 1722, en: G. SoLís RoBLEDA (ditora) Contra viento y marea..., 80

32 Carta del obispo al rey informando la cancelación del servicio, Mérida, 9 de marzo de 1723, en G. Solís RoBledA, editora, Contra viento y marea..., 94: «...perdiéndome el respeto para provocarme como a mí antecesor y ponerme en tales lances que me viese precisado a desistir del intento principal».

Hispania Sacra, LXIII

128, julio-diciembre 2011, 469-499, ISSN: 0018-215-X 
autoridad real, que dicen tienen [...] con los trabajos de advertir displicentes a estos habitadores por hallarse oprimidos al yugo de los eclesiásticos [...] como lo han experimentado los seculares de primera distinción de esta ciudad en el mismo reverendo obispo a quienes en su casa ha injuriado con palabras impropias y muy ajenas de las que debe proferir su dignidad. 33

El gobernador no mencionaba la comisión especial que el obispo había recibido del monarca, y, por el contrario, lo trataba como un intruso de la jurisdicción real, consciente quizá de la sensibilidad que en Madrid había sobre ese tipo de acusaciones. ${ }^{34}$ En un intento por minar el apoyo de Madrid al prelado, Cortayre llegó a expresar que, en el fondo, los eclesiásticos querían ser poderosos para quedarse con todos los beneficios de los repartimientos. ${ }^{35}$

El cabildo de la ciudad de Mérida no se quedó atrás en la contraofensiva al obispo, dado que sus miembros también eran de los principales beneficiados de los repartimientos, a los que catalogaban como «suave yugo de la fe» y muy moderados para los indios. Señalaban al rey que los curas se beneficiaban por igual del trabajo de los indios para sus propios negocios y empresas económicas. ${ }^{36} \mathrm{El}$ verdadero propósito del obispo era, según los capitulares: «...despoblar la ciudad y toda la provincia, oponiéndose a vuestra real jurisdicción».37 El remedio deberían ponerlo los gobernadores, no el obispo, pues los jueces eclesiásticos perturbaban las jurisdicciones.

Los otros dos cabildos de españoles, Valladolid y Campeche, se unieron contra el obispo, expresando que perturbaba a la provincia, creía saber más que todos y no comprendía, porque Yucatán había podido mantenerse por dos siglos

${ }^{33}$ Informe del gobernador de Yucatán al rey rebatiendo el memorial del obispo, Mérida, 2 de julio de 1723, en: G. Solís RoBlEDA, editora, Contra viento y marea..., 121.

${ }^{34}$ El gran intento del arzobispo Lanciego, por los mismos años, para secularizar 60 doctrinas del arzobispado, que había recibido inicialmente el apoyo real, fracasó cuando los franciscanos convencieron al monarca que el primero había violado el real patronato. R. AGUIRRE, Un clero en transición..., capítulo VIII, «El designio político de Felipe V: clérigos útiles, frailes sujetos».

35 Informe del gobernador de Yucatán al rey rebatiendo el memorial del obispo, Mérida, 2 de julio de 1723, op. cit..122: «...tener toda la autoridad los eclesiásticos para con ella adelantar sus conveniencias, que no habiendo otro comercio en esta tierra que el de los frutos que han de cultivar y solicitar los indios, han de ser precisados los seculares a hacer solamente aquel que no quisieren para si los doctrineros, que la solicitud de intereses en el tiempo presente en esta tierra es la mayor por los eclesiásti$\cos \ldots \gg$

${ }^{36}$ El cabildo de Mérida al rey, a favor del servicio y porque se suspenda la comisión especial al obispo, 3 de julio de 1723, en: G. Solís RobledA, editora, Contra viento y marea..., 130: «...se pase tan en silencio -con el supuesto que se asienta en el memorial por cierto de estar todo lo eclesiástico remediado- el copioso número de milperías del mismo género que con la misma paga, y no pocas veces sin ella, labran para los curas seculares y eclesiásticos los indios en el partido de la villa, como vuestra majestad habrá reconocido en el memorial del procurador de la villa de Valladolid...»

37 Ibidem 131 . 
«en política y cristiandad» con los repartimientos de los indios; insistieron en «desenmascarar» los verdaderos intereses del clero al señalar que los principales favorecidos de los contribuciones de los indios eran los curas, los colectores del diezmo y los receptores de Cruzada. De los primeros, en especial, los acusaban de ser los verdaderos responsables de la fuga de indios de sus pueblos:

[...] los indios de los curatos de regulares se pasan a los de los seculares, no porque contribuyan a unos más que otros, sino porque los primeros se mudan según sus capítulos intermedios y precisan a los indios a que contribuyan las limosnas con más puntualidad que los segundos a causa de ser vitalicios, no obstante de que en poder de éstos les trabajan en milpas de algodón y maíz. Lo segundo, porque estando los indios en las estancias, ranchos y milperías, siendo los dueños españoles, logran éstos las semillas y pagan los diezmos, y si los indios trabajasen para sí en sus pueblos se menoscabarían dichos diezmos en perjuicio de vuestro reverendo obispo, por ser exentos los indios de esta paga. Estos fueron los motivos y la influencia de los curas seculares: por no desasirse de los indios que en sus curatos hay y pertenecen a los regulares porque no se ejecutó la reducción $[\ldots]^{38}$

Exageradas o no, estas acusaciones dan cuenta sobre la disputa de los feligreses en los curatos de Yucatán, evidenciando que los indios no sólo huían de los españoles sino también de sus ministros espirituales, ${ }^{39}$ estrategia antigua y que también se practicaba en curatos del norte del arzobispado de México. ${ }^{40}$

Luego de esta andanada de acusaciones, los regidores llegaban al mismo punto que el gobernador: los clérigos encarcelaban a seglares y hacían lo que querían, introduciéndose en la jurisdicción real. ${ }^{41}$ Por ello, debían ser frenados, se les debería imponer un arancel fijo y los indios sólo debían pagar en dinero. Respecto a los cultivos que los «cantores y músicos» hacían para sus curas, debían prohibirse. Los diezmos, continuaban, no deberían colectarse por enviados del obispo y del cabildo eclesiástico, sino por el gobernador y sus repartidores de mercancías, para evitar sus abusos.

Los indios que vivían en las estancias de ganado, debían regresar a sus pueblos así como los que vivían alrededor de cofradías, en estancias. El obispo ca-

\footnotetext{
${ }^{38}$ Representación al rey del procurador de la ciudad y villas de Yucatán pidiendo se suspenda la comisión especial del obispo, México, 4 de septiembre de 1723, en: G. Solís RobledA, editora, Contra viento y marea...143-144.

${ }^{39}$ Ibidem 147. Los capitulares expresaron que era a los eclesiásticos a quienes más contribuían los indios, algo que el obispo ocultaba; que los encomenderos, por el contrario, eran buenos, esperaban a sus indios para la paga de su tributo y recibían a los huérfanos en sus casas para mantenerlos, educarlos y adoctrinarlos.

${ }^{40}$ Rodolfo AgUiRRE, «Rentas parroquiales y poderes locales en una región novohispana. Yahualica, 1700-1743», en: F. J. CeRvantes Bello, (coord.) La Iglesia en Nueva España. Relaciones económicas e interacciones políticas, México, BUAP, 2010, 115-142.

${ }^{41}$ Ibidem 145.
} 
recía del conocimiento y la experiencia de la provincia, por lo cual solicitaban la suspensión de su comisión. En medio de todo ello, Gómez de Parada emprendió la reforma de las obvenciones, tratando de enmendar a su clero.

\section{LA VISITA EPISCOPAL A CURATOS Y DOCTRINAS}

A pocos meses de su arribo a Yucatán, el obispo recibió una real cédula de junio de 1715 que resumía las vejaciones a los indios por parte de los españoles, los curas y los colectores del diezmo:

[...] con la vecindad que tienen en sus pueblos los españoles, mulatos y mestizos, haciéndoles graves molestias en sus sementeras y ganados, hallándose asimismo oprimidos con las contribuciones que han introducido los curas y párrocos -así seculares como regulares- demás de las obvenciones que para su congrua sustentación contribuyen los referidos indios, las cuales cobran con el rigor de diferentes apremios; a que se añaden las extorsiones que les ocasionan los colectores de diezmos, pues demás de los repartimientos [...] pasan también al exceso de cobrarles en frutos, vendiéndoselos a los mismos indios a precios muy subidos, y obligándolos a que los conmuten con otros géneros de mayor estimación. Padeciendo asimismo el perjuicio de que los ministros de doctrinas se sirven de los indios y los relevan de tributos. ${ }^{42}$

Estas acusaciones pesaron mucho en el ánimo del prelado puesto que hacían cargar el peso de la opresión indígena en la Iglesia misma. En consecuencia, Gómez de Parada se dispuso a averiguar el fondo de las mismas. El obispo emprendió entonces una visita a toda su jurisdicción, entre 1719 y 1720 «...para examinar por mí mismo y ver todo lo digno de remedio». ${ }^{43}$ Sobre la marcha, el obispo fue dando medidas que comenzaron a llamar la atención de todos: «...como sol de su Iglesia ha salido a visitar los lugares más remotos de su distrito que el tiempo le ha concedido [...] descubriendo, desterrando y puniendo tantos abusos (siendo los primeros en quien lo ejecutó sus mismos testigos) que han hecho levantar el grito a los poderosos de allí, resentidos de perder las inicuas comodidades que en el sudor de tantos indefensos tenían».44

En Madrid se seguía de cerca la situación yucateca pues otra cédula de febrero de 1716 ordenó al prelado arreglar los derechos parroquiales. En respuesta, el prelado elaboró aranceles específicos para cada curato o doctrina; luego informaría que los indios estaban felices con ello y que había multado a curas

\footnotetext{
${ }^{42}$ G. Solís RobledA, (editora), Contra viento y marea..., 5. La misma cédula hacia responsables tanto al obispo como al gobernador, de remediar la situación, tarea que, como veremos, cada dignatario entendió de diferente manera.

${ }^{43}$ Idem., 6.

44 Juan Francisco de Córdoba, procurador del obispo Gómez de Parada ante la real audiencia de México, 17 de abril de 1723, en: G. Solís RobledA, editora, Contra viento y marea..., 98.
} 
por no cumplirlo. En 1721 envió copia de los mismos a Madrid e informó que convocaría a un sínodo diocesano para arreglar todo.

En cuanto a la mano de obra para curas, el obispo defendió la libertad de trabajo de los indios, asunto del que se habían vertido duras críticas. ${ }^{45}$ En plena visita al curato de Dzonotpip, en 1719, el obispo abordó ya el asunto: «...ni se les ocupe a dichos cantores y sacristanes ni a los indios del servicio de la casa del cura en otros oficios más que en los de su destino, pagando a éstos últimos su servicio sin ocupar más de cincuenta, poco más o menos, en estos empleos y sus remudas». ${ }^{46}$

Esta concepción de indios libres soslayaba los lazos que, como miembros de una comunidad, los unía a una república de indios o a los caciques, pues desde las leyes mismas, los naturales eran considerados miembros de una colectividad de la que se derivaban obligaciones, entre ellas la prestación de servicios personales para obligaciones comunes. ${ }^{47}$ No es que el obispo desconociera todo ello, pero trataba de separar el trabajo de los indios que demandaban los curas y españoles.

Otro fenómeno que estaba preocupando a los poderes provinciales era el de la emigración de los indios de pueblo a las explotaciones agrícolas particulares. Los feligreses se quejaban de que los «fugitivos» huían de sus obligaciones parroquiales, dejando toda la carga a los que permanecían. Por ello, Gómez de Parada, durante su visita «...mandó estrechamente a los curas y ayudantes que todos los domingos del año una hora antes o en la inmediata después de misa en todos los pueblos donde la fuesen a dar expliquen con todo desvelo la doctrina cristiana, corrijan los vicios en que están envejecidos y los exhorten a la reformación de vida...»48

\footnotetext{
${ }^{45}$ Representación del procurador de la provincia contra la aprobación del sínodo celebrado por el obispo de Yucatán, México a 18 de enero de 1725, en: J. Gómez DE PARADA, op. cit. 356: «...los del pueblo de Sahcabchén añaden que todas las semanas dan a su beneficiado seis indias y cinco indios de servicio por el que nada les paga y que en el empleo de cantores, sacristanes y otros sirvientes tienen todo el año embebidos y ocupados cincuenta indios [...] que a éstos los ocupa en el cultivo de sus milpas teniendo al presente labrados setecientos mecates, que pagan en exceso las obvenciones [...] Los del pueblo de Chicbul expresan que el cura los obliga a que contribuyan lo que excesivamente dan en copal, no queriéndoles recibir la paga en reales, lo que les sirve de notable perjuicio por el trabajo que tienen en irlo a buscar a los montes [...] Considere [...] vuestra alteza sino sucederá lo propio en los patíes, queriendo los curas sean más anchos y largos que los del comercio y sin no acontecerá lo propio con las legumbres...»

46 Auto de absolución del obispo Gómez de Parada a los religiosos de Dzonotpip por pesquisa en visita general, 19 de diciembre de 1719, en: J. GómEZ DE PARADA, op . cit. 283.

${ }^{47}$ En este sentido N. M. FARRIS, o cit., ha subrayado la importancia que la colectividad tenía para los indios mayas en todos sentidos.

48 Auto de absolución del obispo Gómez de Parada a los religiosos de Dzonotpip por pesquisa en visita general, 19 de diciembre de 1719, en: J. GómEZ DE PARADA, op . cit. 283.
}

Hispania Sacra, LXIII

128, julio-diciembre 2011, 469-499, ISSN: 0018-215-X 
Al finalizar su visita, el prelado hizo un sustancial informe a la corona en el cual, a la vez que matizaba las acusaciones al clero, trató con dureza al gobernador, encomenderos, capitanes de milicias y regidores de los ayuntamientos de Mérida, Valladolid y Campeche. El documento es una radiografía sobre el estado del trabajo y la productividad indígena en Yucatán. ${ }^{49}$

Varias problemáticas fueron abordadas por el prelado, para lo cual contó con la ayuda de un clérigo de la región al que consideró una persona honrada y bien informada de las «cosas» de la tierra. ${ }^{50}$ Según el obispo, lo menos gravoso para los indios eran las obvenciones parroquiales «...por cobrarse en muy menudas cantidades a muchos plazos del año, lo que no sucede en los tributos y repartimientos que se cobran en sólo dos plazos».51

Afirmó que castigaría a los malos curas, aunque en la visita no había encontrado que los doctrineros relevaran de tributos a los indios que servían en las iglesias; antes bien, músicos, cantores, maestros de capilla y de doctrina seguían pagándolos, aunque por ley estaban exentos. En cuanto al señalamiento de que la Iglesia ocupaba a muchos indios, el prelado expresó que esta situación se debía a que los mismos, por exentarse de las cargas de sus pueblos, se hacían cantores y sacristanes. Algo similar ocurría con los que se iban a estancias y ranchos. 52

La fuga de indios a los curatos o ranchos, lejos de ser rechazada por el obispo, la justificaba como una forma de protegerlos; por ello, había permitido que los curas los congregaran «...donde con su protección -y no tener cacique por cuyo medio se les puedan imponer las cargas referidas- vienen a vivir gustosos y aliviados con sus casas, sembrados y mejor policía, doctrina y forma de pasar que en los pueblos formales...» ${ }^{53}$ Debido a ello, el prelado no había reducido el número de cantores, pues de haberlo hecho, expresó, los indios no se hubieran ido a sus pueblos sino a los ranchos o los montes.

Sin duda, cuidaba al clero parroquial en su informe pues poco le convenía enemistarse con él, consciente de que era el sector crucial para las reformas que se pretendía; cuando mucho, aceptó que había ciertos excesos en el cobro de

\footnotetext{
${ }^{49}$ Carta del obispo al rey denunciando los males de los indios de 30 de julio de 1721 , en: G. SoLís RobledA, (editora), Contra viento y marea..., 5-20.

50 Ibidem 10: Gómez de Parada envió a su secretario, notario e intérprete, br. Luis Coello Gaytán, para dar cuenta en la corte sobre las cargas y daños a los indios. Decía que gracias a su secretario «...he llegado a comprender lo que otros prelados no han podido alcanzar por falta (entre otras cosas) de ministros fieles y temerosos de Dios».

51 Ibidem 8.

52 Ibidem 10: «...es de considerar cuán graves son las cargas que los desdichados indios tienen en sus propios pueblos, pues por sólo librarse de ellas tienen por conveniencia el trabajar de balde y sin sustento alguno a favor del cura o dueño de estancia...»

53 Ibidem 16.
} 
obvenciones y en la prestación de servicios personales, evitando hablar de su participación en los repartimientos de géneros y de dinero. Aunque admitió que los colectores del diezmo sí participaban del reparto de mercancías, no les reconocía los excesos de los otros involucrados.

Por el contrario, el obispo afirmó que, como los encomenderos se negaban a pagar el diezmo de sus tributos, los colectores lo pedían entonces a los caciques, quienes volvían a cobrarlos por concepto de los indios fugitivos, pobres o inválidos; para lograrlo, los caciques repartían algodón extra a las indias, para que del salario de éstas se pagara. Para terminar con esta situación, Gómez de Parada ordenó a los colectores que sólo cobraran a los encomenderos, e hizo unas instrucciones breves y claras, y a los indios les explicó que no debían pagarlo a nadie más. ${ }^{54}$

El obispo cerró su informe con un balance sobre su propia actuación, considerando que durante la visita había reformado todo lo que había podido conforme a los concilios de Lima y México, especialmente en su propia familia, en el clero parroquial y en el clero en su conjunto, estableciendo una disciplina que, desde su punto de vista, no habían conocido antes: expulsó a clérigos «indignos», examinó personalmente a los nuevos sacerdotes ordenados así como a los clérigos durante su visita, obligó a los estudiantes a estudiar más y asistir a conferencias morales, y examinó detenidamente a los opositores a curatos..$^{55}$

Gómez de Parada era congruente con la política borbónica de reforma del clero que estaba siendo impulsada luego del fin de la guerra de sucesión, tal y como intentaba hacerlo por los mismos años Lanciego Eguilaz en el arzobispado de México. ${ }^{56}$

\section{EL SÍNODO DE MÉRIDA Y LA REFORMA DE LAS OBVENCIONES PARROQUIALES}

Después de la visita a la diócesis, el activo obispo convocó a un sínodo diocesano en 1722 al que acudieron como figuras centrales los curas, a quienes intentó comprometer con la reforma, advirtiéndoles que no toleraría que siguieran abusando de sus feligreses ${ }^{57}$ En la introducción del sínodo se expresó

${ }^{54}$ Ibidem 18-19.

55 Ibidem 17: «La cual he ido con toda prolijidad plantando de nuevo, y en todo y por todo dándola a conocer a estos pobres eclesiásticos ciegos, que tanto han pecado y errado por no saber el camino ni habérseles dirigido por él y corregido».

${ }^{56}$ R. AgUIRRe, Un clero en transición..., capítulo II: «La ordenación sacerdotal: críticas en Madrid y aumento de exigencias en México»

57 «Petición del obispo al rey, en donde informa el envió de su representante al consejo y sobre la ejecución de la real provisión. Mérida, 12 de noviembre de 1722», 3, 66: «...puse en mi sínodo estatuto con pena grave a los curas para que por su parte la cumpliesen, no sólo absteniéndose de dar -por 
que las largas y penosas distancias y la falta de ministros habían sido «...causa de no haberse podido jamás congregar dicho sínodo y que éste es el origen de haberse gobernado generalmente esta diócesis sin regla cierta en tantas materias cuantas son las que en sínodo deben arreglarse».58

La realización del sínodo fue todo un logro para Gómez de Parada, teniendo en cuenta que el clero parroquial saldría afectado directamente con la reforma de las obvenciones pretendida. De esa manera, el obispo era consecuente con la línea política establecida en Madrid, que veía en esas asambleas del clero una vía franca para la reforma de la Iglesia y del clero. Con todo, este logro en Yucatán no se repetiría en alguna otra diócesis novohispana por esa época.

Las reuniones sinodales fueron todo un acontecimiento político, dado que sus resoluciones eran parte del proyecto episcopal que buscaba, por un lado, remediar los problemas al interior de la Iglesia, y por el otro, servir como foro para exponer la opresión generalizada de los indios en la provincia. Gómez de Parada convirtió su palacio en el centro de las decisiones para la reforma del clero y del trabajo indígena, escudado en su jurisdicción episcopal y la comisión del rey. Para ello, pretendió usar intensivamente los tribunales eclesiásticos, ordinarios y foráneos, como garantes de que en los curatos se aplicaría la reforma del trabajo indígena, mientras que en las villas y ciudades de españoles se harían cargo los vicarios foráneos. Todo ello cuestionó la capacidad del gobernador de Yucatán para solucionar los problemas sociales de los indios.

Gómez de Parada se dispuso a reformar las obvenciones por dos vías: un arancel general y la regulación de las relaciones de trabajo de los indios con sus curas, más allá de sus deberes parroquiales. Así, en el sínodo se establecieron aranceles para los tribunales eclesiásticos y para las parroquias, a la vez que procuró no entrometerse en materias de real patronato para no dar pie a futuras impugnaciones. ${ }^{59}$

Estaba convencido que la mejor solución para evitar los abusos de los curas era imponer tasas fijas y generales, a pesar de que intentos similares en épocas pasadas fracasaron. ${ }^{60}$ El obispo señaló que se habían dispuesto pagos más mo-

medio de los caciques- servicios (como hacían algunos sin haber quien me los hubiese denunciado) sino también ejecutando puntualmente lo que vuestra alteza se sirvió de mandarles en dicha real provisión...»

58 J. Gómez De PARADA, op. cit., 11.

59 «Carta al rey del obispo Gómez de Parada sobre los resultados del sínodo, Mérida a 30 de mayo de 1723», en: J. GómEZ DE PARADA, op. cit., 309. Al final, el obispo pedía la rápida autorización del sínodo.

60 Ibidem 307: «...se originaron infinitos abusos de los curas, gravámenes y opresiones de los miserables indios que sólo han reclamado los encomenderos y gobernadores cuando se han intentado corregir los suyos, queriendo el que se compensen los unos con los otros para tragarse unos y otros al indio miserable». 
derados y prohibido a caciques hacer cobros extraordinarios, provocando su disgusto y el de los encomenderos.

Se estableció que sólo pagarían obvenciones los hombres de entre 14 y 60 años, y las mujeres, de entre 12 y 55. Los primeros entregarían al año 12.5 reales y las mujeres 9, dentro de lo cual ya estaban incluidas las contribuciones para las fiestas del santo patrón y de los fieles difuntos. Los bautizos se pagarían a 3 reales, los casamientos a 8; por entierro o testamento, sólo se daría algo por concepto de misa, siempre y cuando el indio lo consintiera, entregando 14 reales si era celebración cantada y 6 si fuese rezada. El pueblo pagaría la comida del cura, si se trataba de un pueblo de visita y no debía darle nada más, quedando desterradas también las limosnas de cuaresma, de pascua, de los jueves, las gallinas para alimentos de los curas o los utensilios para la cocina conventual. También quedó estrictamente prohibida cualquier forma de servicio personal no remunerado. 61

Uno de los puntos más controvertidos fue la flexibilidad que el sínodo dio a los indios para pagar en géneros o en dinero, a pesar de la insistencia de los regidores de Mérida para restringirlos a lo segundo. Según el obispo, los regidores sabían bien que los nativos sólo podían adquirir numerario aceptándolo de los repartidores de mercancías y dinero: «...manifiestamente se reconoce que si a ésos se obligase a pagar en dinero precisamente sus derechos parroquiales, se verían obligados a recibir mayor número de repartimientos de sus gobernadores y encomenderos, y los demás vecinos que no lo son, deberían perecer por no quedarles el único trato del rescate de los géneros de los curas». ${ }^{62}$ Es decir, para el prelado, el que los curas pudieran cobrar sus obvenciones en géneros era una forma de moderar el monopolio del comercio de los otros grupos de poder, argumento que defendió hasta el fin. Para los indios, según el mismo, era más cómodo pagar en especie, pues si tuvieran que vender su cera para pagar en dinero las obvenciones, la comprarían a mitad de precio e igual sucedería con el algodón.

Gómez de Parada fue más intransigente en el asunto de los servicios personales a los curas consciente de que por mucho tiempo habían sido comprendidos como parte de los derechos parroquiales, especialmente de los indios de Iglesia, sin embargo los prohibió resueltamente: «Los sacristanes, cantores y niños de doctrina no los debe ocupar el cura para servirse de ellos y a los indios que ocupasen en su servicio debe pagarles como los demás vecinos sin diferen-

61 «Arancel de los derechos parroquiales que todos los indios de pueblos, sitios, ranchos y estancias de este nuestro obispado deben contribuir a sus curas cada año», en: J. GómEz DE PARADA, op. cit. 60 .

${ }^{62}$ Carta al rey del obispo Gómez de Parada sobre los resultados del sínodo, Mérida a 30 de mayo de 1723, en: J. Gómez De PARADA, op. cit. 306.

Hispania Sacra, LXIII

128, julio-diciembre 2011, 469-499, ISSN: 0018-215-X 
cia alguna». ${ }^{63}$ Como complemento a esto, se dispuso reglamentar abiertamente la contratación de indios feligreses como asalariados de los curas, separando tal situación de las obvenciones y bajo ciertas condiciones:

Asimismo el eclesiástico puede para su gasto y no más, sin hacer fuerza y pagando su justo estipendio, hacer que los indios le tejan o hilen patíes y otras telas de la misma suerte que puede mandar a un sastre que le haga de vestir, pero no puede mandar hacer las dichas telas ni menos comprarlas hechas -ni otro género alguno- en cantidad considerable para que se vendan $[\ldots]^{64}$

Y en cuanto a la explotación de cultivos, el sínodo también dispuso el permiso a los curas para tenerlos siempre y cuando se acudiera a la libre contratación de los indios asalariados:

[...] teniendo sujeto a propósito que quiera arrendar estancia alguna de cura o tierras las arrienden [...] pero si no hallasen sujeto a propósito que las pueda arrendar se les permite el administrarlas por sí y labrar las tierras, con tal que no hagan fuerza a los indios que le hayan de servir y les haya de pagar su justo estipendio como otro cualquier seglar [...] permitimos, con mayor razón a los curas que por la cortedad de sus curatos no tienen la congrua sustentación, el que puedan tener estancia y labrar la tierra para tener la competente, sin perjuicio del prójimo ni del cumplimiento de su cargo principal. ${ }^{65}$

Igual de complicado era reglamentar que el comercio de los curas con los indios fuera independiente del repartimiento de mercancías y dinero que el obispo tanto criticaba al gobernador. Sin eludir el asunto, las constituciones sinodales permitían tener tratos con los indios de sus géneros y cultivos, señalando algunas limitaciones:

[...] que el eclesiástico, no haciendo fuerza a lo indios y pagándoles su justo precio o justo estipendio, puede comprarles sus cosas o géneros -como no sea para vender-y darles que hacer y que trabajen [...] y así puede cultivar el campo y tener milpa, estancia o colmenar y transportar sus frutos y venderlos dónde y por el precio que los demás, como lo hacen sin el menor reparo en la Nueva y Vieja España y se declaró por la ley real aun para los prelados el que pueden embarcar los frutos de su renta. ${ }^{66}$

Una vez asentado lo anterior, el sínodo prohibió a los curas ser intermediarios o traficantes de géneros para terceras personas, tratando evidentemente de independizar los ingresos parroquiales de los repartimientos:

\footnotetext{
63 Parágrafo cuarto, párrafo tercero de los aranceles y obvenciones para los indios de pueblos, sitios, ranchos y estancias de la diócesis de Yucatán, en: J. GómEz DE PARADA, op. cit. 251.

${ }^{64}$ Párrafo segundo, libro tercero, título vigésimo: De clerici vel Monachi negotiis secularibus se immisceant, en: J. Gómez De PARADA, op. cit. 184.

65 Ibidem, párrafo tercero, libro tercero, título vigésimo, 185.

66 Ibidem, párrafo segundo, libro tercero, título vigésimo, 184.
} 
[...] en ningún caso los eclesiásticos obliguen a los indios a que les tejan patíes, declaramos por nulas y de ningún valor todas cualesquiera escrituras, vales o cualesquiera otro instrumentos de obligación hechos en cualquiera forma por eclesiástico de entregar cantidad alguna de patíes a cualquier persona y les absolvemos de la obligación de entregarlos como de obligación de cosa ilícita y prohibida a ellos, pues lo es a los eclesiásticos el mandar hacer patíes de cuenta de otro ni de la suya y el comprarlos para vender. ${ }^{67}$

Como complemento a todo lo anterior, el obispo reunió en su palacio a los mercaderes para informarles que los tratos con los indios debían hacerse en adelante en forma directa, sin intermediarios. Prohibió al capitán de la sierra regresar ahí para que no siguiera vejando a los indios con sus repartimientos, pero finalmente había regresado, y con ello, estaba instaurando nuevamente el antiguo orden.

El gobernador y los cabildos habían intentado convencer a jesuitas y franciscanos de testificar a favor del antiguo orden, a lo que se negaron y, en consecuencia, pidieron su destierro. En cuanto a los españoles, mulatos y mestizos avecindados en los pueblos, resultó que por lo regular eran criados o ministros para los repartimientos de los poderosos, o también parientes o compadres de los curas. Mandó a traer a varios de ellos y les ordenó dejarán de molestar a los indios. ${ }^{68}$

No obstante el esfuerzo porque la reforma tuviera fuerza mediante el sínodo, las cosas comenzaron a complicarse para el prelado no bien acabaron las reuniones sinodales: franciscanos y clérigos se unieron en contra de las resoluciones.

\section{RESISTENCIA CLERICAL Y VINCULACIÓN A LA OPOSICIÓN GENERAL: CLÉRIGOS Y FRAILES SE UNEN}

El arancel de obvenciones incomodó por igual a curas seculares y a doctrineros, acostumbrados a imponer sus propias condiciones, a tal grado que se unieron para frenar su aplicación, olvidando sus antiguas diferencias. Este hecho nos indica claramente que la reforma del obispo iba mucho más allá de algo coyuntural y que afectaba por igual a todo el clero yucateco; igualmente, nos señala el momento en que Gómez de Parada perdió el control de su diócesis, y en consecuencia, se quedó sólo, desde el punto de vista político, frente al resto de los poderes provinciales. Por otro lado, la oposición clerical generalizada marcó también los límites del apoyo de la corona al prelado, pues una cosa era

\footnotetext{
${ }^{67}$ Ibidem, párrafo sexto, libro tercero, título vigésimo, 186

${ }^{68}$ Informe del obispo al rey, Mérida, 4 de abril de 1724, en: G. Solís RobledA, (editora) Contra viento y marea..., 167.

Hispania Sacra, LXIII

128, julio-diciembre 2011, 469-499, ISSN: 0018-215-X
} 
intentar reformar al clero y otra diferente era provocar una agitación política de toda una provincia indiana cuyas consecuencias nadie podía proveer. ${ }^{69}$

Enfrentar a los franciscanos, en especial, fue una de las tareas más complicadas debido al peso social y político que tenían en la península. Cuando el obispo pretendió que se sujetaran a la jurisdicción episcopal y se limitaran a las funciones puramente doctrinales y de administración de sacramentos en los indios, los religiosos protestaron con fuerza, sabedores de que el prelado ya tenía varios «frentes de batalla» como para enfrascarse en otro. Aceptar un cambio en el régimen de obvenciones significaba, ni más ni menos, cambiar la principal base económica de los religiosos, con todo lo que ello implicaba.

Por entonces, la provincia de San José comprendía 31 conventos, 30 cabeceras de doctrina sin contar sus pueblos de visita y a casi 200 frailes. ${ }^{70}$ Los montos de las obvenciones franciscanas llegaron a superar los tributos reales o de los encomenderos. Rocher Salas calcula que los franciscanos podían recaudar alrededor de 67000 pesos anuales, mientras que los encomenderos llegaban a 65000. Por su parte, el diezmo que colectaba la mitra apenas sumó 17406 pesos en 1757, menos de la cuarta parte de los ingresos franciscanos. ${ }^{71}$

Olvidándose un tanto del bienestar material de los indios, los franciscanos dieron prioridad a sus propios intereses. Pero no se trataba sólo de defender lo económico, sino también su independencia, su prestigio y sus privilegios como orden religiosa. En octubre de 1722, recién terminado el sínodo de Mérida, el vicario provincial franciscano avisó al procurador general de su orden que el arancel disminuía los ingresos de las doctrinas por lo cual no se podrían sustentar sus ministros, vislumbrando ya una alianza con los clérigos. El vicario pedía suspender la aplicación del sínodo pues daba poderes al obispo sobre los religiosos que vulneraba sus privilegios y exenciones. ${ }^{72}$ Igualmente, expresaba que los indios sí estaban sujetos a ellos y podían mandarlos, como sus súbditos.

\footnotetext{
69 Varios estudios han hecho alusión a esta defensa conjunta, el más reciente: A. RochER SALAS, op. cit. 66. Sin embargo, ninguno lo ha contextualizado en el marco de las nuevas políticas eclesiásticas de Felipe V.

70 Ibidem 109-111.

71 Ibidem 142-143.

72 «Petición del apoderado de los franciscanos al rey representando su oposición a varios puntos del sínodo, México a 4 de noviembre de 1723», en: J. GómEZ DE PARADA, op . cit. 316-317. Alegaban que los frailes no tenían porque explicar a los obispos las causas de remoción de los doctrineros sino sólo al vicepatrono; que el obispo no podía dar licencias de confesar a un religioso sólo por tiempo limitado; que el sínodo infringía el concilio III mexicano al declarar que los feligreses de las doctrinas no estaban sujetos a los doctrineros en cosa alguna y que el sínodo no podía establecer penas contra doctrineros, salvo en su oficio de curas, pero ello no le daba facultad al obispo para hacer estatutos penales.
} 
Según testigos españoles, continuaba, los doctrineros no abusaban del cobro de limosnas u obvenciones y para recaudarlas no habían usado de la fuerza. Explicaba que el obispo antecesor, fray Pedro de los Reyes, había reconocido su gran labor, y que incluso ordenó que todos los indios de estancias, milpas y ranchos que no les pagaban derechos, lo hicieran como los de los pueblos. Por ello, pedía que una cédula que ordenaba a los obispos castigar a los religiosos, no se insertara en el sínodo, pues sólo servía para deshonrar a su provincia. ${ }^{73}$

El clero diocesano se adhirió a los franciscanos para nombrar a un procurador común ante la real audiencia de México para defenderse de las reformas episcopales. ${ }^{74}$ Ambos cleros se aliaron en contra del nuevo arancel y la reforma del trabajo indígena en los curatos, buscando la suspensión hasta que el rey estuviera bien informado de sus inconvenientes. Desde su punto de vista, los indios de Yucatán habían pagado siempre sus obvenciones voluntariamente. Insistían en que las nuevas tasas eran insuficientes y que una cédula de 1712 había ordenado que su pago se atuviese a la costumbre.

Aunque coincidían con el obispo en los pagos en especie, ${ }^{75}$ pedían que la mano de obra de los indios siguiera siendo parte de los derechos parroquiales, pues la misma compensaba la falta del sínodo real que la real hacienda sí pagaba en otras diócesis.

Los curas, continuaban, debían vivir decentemente, lo que incluía, aparte de los alimentos: «...el vestuario, médico y medicinas, libros y cabalgaduras, y en los clérigos a la manutención de una moderada familia, como en los regulares a las precisas cargas con que deben contribuir [...] a los gastos de su provincia, fomento de estudios, noviciado y expensas de misiones y socorro de enfermería... $\gg^{76}$ Por otro lado, se quejaban de que en Yucatán los curatos no tenían otro tipo de rentas ni ayuda del rey, y que los encomenderos daban una muy pobre ayuda. ${ }^{77}$

${ }^{73}$ Idem.

${ }^{74}$ Idem.

75 «Petición de los franciscanos y de los curas seculares representando su oposición al arancel de limosnas y obvenciones, México a 15 de noviembre de 1723», en: J. GÓMEz DE PARADA, op. cit..332: Alegaban que era más benéfico para ellos pagar en los géneros que se producían en las regiones de donde eran nativos: «...y por esto en el partido de La Sierra donde hay abundancia de miel y no se coge sal daban la miel doble y no daban limosna de sal y en el partido de La Costa donde no es la miel tan abundante y tienen a la mano la sal daban una limosna de miel y otra de sal...»

76 Ibidem 333.

77 Ibidem 334: «...De manera que no hay otra cosa de dónde haya de salir el mantenimiento de los curas, ornato del culto divino, fábrica y reparos de las iglesias y casas, vino, aceite y cera, sino de la congrua asignada en el arancel ya referido. Y siendo las más de las dichas doctrinas cortas de feligreses vendrían a notable deterioración y lastimosa el culto divino y las iglesias porque no podrán los curas atenderlas, aunque quieran».

Hispania Sacra, LXIII

128, julio-diciembre 2011, 469-499, ISSN: 0018-215-X 
Según los quejosos, con el nuevo arancel, en cada doctrina el monto de las obvenciones quedaría en no más de 1000 pesos, cantidad insuficiente, pues en cada partido de 800 tributarios tenían un cura y dos ministros, por lo menos, mientras que en aquellas que tenían el doble de tributarios había hasta 8 religiosos. Negaban que los religiosos tuvieran cultivos pues sólo los tenían algunos curas clérigos; pedían que los indios nobles también pagaran derechos parroquiales así como que los dueños de estancias y ranchos pagaran los de sus trabajadores y no los ocultaran, pues para atenderlos se necesitaban más ministros. Cobrar menos derechos a los indios, finalizaban su alegato, significaba que a fin de cuentas gastarían más en aguardiente y borracheras.

\section{OPOSICIÓN GENERALIZADA Y REPLIEGUE DE LA REFORMA}

El sínodo celebrado, sumándose a las restricciones que el obispo, en su calidad de comisionado real, estaba imponiendo en referencia al trabajo forzoso de los indios, provocando una mayor irritación. Los regidores de Mérida, en especial, estuvieron atentos de las resoluciones sinodales, actuando en consecuencia. Aunque se reunieron con el obispo, no llegaron a ningún acuerdo. No obstante que Gómez de Parada quiso desligar al sínodo de su comisión real, en la práctica todos entendieron que se trataba de lo mismo: el trabajo de los indios y sus beneficiarios, por lo cual creció la oposición a la mitra, encabezada por el gobierno de Yucatán y los regidores de los cabildos españoles, que persistieron en evidenciar los abusos de la Iglesia como estrategia central.

Así, el abogado, el defensor y el procurador de los indios expresaron al obispo que ellos y el gobernador administraban justicia a los indios, por lo que el sínodo no debía tratar del asunto. ${ }^{78}$ En su lugar, debía arreglarse el que los curas estuviesen aumentando las obvenciones; que no había regla general para cobrarlas pues si había cosechas abundantes, se les cobraba en dinero, el cual los curas lo entregaban a los caciques para que estos les compraran los géneros (maíz, frijoles, chile y miel) a los indios a precios bajos; y si, por el contrario, había escasez, les cobraban en especie. Señalaban también que los naturales gastaban mucho en cera, comida de ministros en las fiestas, vino, harina, incienso, limosna de sermón y misas cantadas, pidiendo que en adelante sólo pagaran en reales. ${ }^{79}$

\footnotetext{
78 «Representación al obispo previa al sínodo de los ministros de los naturales, Mérida a 20 de junio de 1722», los ministros eran: Diego de Arroyo, Bernabé Antonio de Mezquita y Cristóbal de la Cámara, en: J. Gómez DE PARADA, op. cit. 285: «...porque fuera mezclar y perturbar las jurisdicciones, resultando de eso que el alivio que se espera en él fuera una conturbación, así en los ánimos como en las jurisdicciones».

${ }^{79}$ Ibidem 286.
} 
Sobre el pago del diezmo, pedían que lo hicieran conforme a la cosecha real de cada año y no conforme a tasas fijas que pasaban por alto la escasez o la abundancia de la época. Finalmente, insistieron en que los indios de Iglesia eran excesivos, pues en algunos pueblos grandes eran 100 y en medianos $50 .{ }^{80}$

Por su parte, los regidores de Mérida afirmaron al rey ${ }^{81}$ que las limosnas eran una carga muy pesada para los indios, que eran extorsionados y maltratados por sus curas, que el nuevo arancel aumentaba la carga de cada feligrés y que el prelado era parcial, por cuanto denostaba los tratos comerciales de los vecinos con los indios y no hacia lo mismo con los que hacían sus ministros. Si el obispo acababa con el comercio de los indios, saldría muy afectado el real erario; además, los curas fungían como jueces y parte acusada en el sínodo, por lo cual mal podrían arreglar el asunto de las obvenciones. Aun más, acusaban al obispo de quedarse con las obvenciones de los curatos vacantes..$^{82}$

Por ello, los regidores pedían que el mismo rey dictara el arancel y que el pago fuera en dinero y no en géneros, que eran lo que ambicionaba el clero, señalando que el ensanchamiento de la jurisdicción eclesiástica era a costa de la real ${ }^{83}$ Hoy por hoy, concluían, no había mayor autoridad en Yucatán que el obispo.

La audiencia de México fue otro foro para atacar al obispo. Un procurador de la provincia ${ }^{84}$ criticó que en el sínodo se calificara a los repartimientos como

80 Ibidem 287: «Siendo ésta una de las causas porque los desamparan y se acogen a ranchos, milpas y estancias y sitios, dando ocasión que por voz común se diga que los tienen ocupados en cortar rollizos, labrar tablones, sacar añil, rozar milpas, asegurando que los beneficios que están en la jurisdicción de Tizimín y Chancenote tienen cultivados sus beneficiados más de doce mil mecates de milpas para la cosecha del algodón».

81 «Representación al rey del cabildo de Mérida contra el sínodo del obispo Gómez de Parada, Mérida a 18 de septiembre de 1722, en: J. Gómez De PARADA, op. cit. 292.

82 «Carta al rey del obispo Gómez de Parada sobre los resultados del sínodo, Mérida a 30 de mayo de 1723», en: J. GómEz DE PARADA, op . cit. 307. El obispo señaló al respecto que los derechos de los curatos vacos pertenecían, por antigua costumbre, al obispo o sede vacante, luego de pagar a los interinos «...lo que tanto habían de sentir los curas mal acostumbrados en los suyos, y no se me ofreció duda alguna cerca de llevar yo estos emolumentos de los curatos vacos desde el día en que vacan hasta el de la colación en virtud de la costumbre, por hallarla aprobada por la constitución 104 de San Pío V...»

83 «Representación al rey del cabildo de Mérida contra el sínodo del obispo Gómez de Parada, Mérida a 18 de septiembre de 1722, en: J. GómEz DE PARADA, op. cit. 295. Los indios de Iglesia estaban siendo protegidos por curas y ministros ante la acción de las autoridades reales: «...introduciéndose del todo en la real jurisdicción el reverendo obispo en la Sínodo... mandando a los curas los defiendan para que se mantengan donde se hallaren y pasen donde quisieren porque con eso consigan librarse de las opresiones de los capitanes, encomenderos y gobernadores, con no poco rubor del actual que se hallaba presente y a quien como vuestro vicepatrón ha dado ínfimo asiento de todo el concurso y negado...»

84 «Representación del procurador de la provincia contra la aprobación del sínodo celebrado por el obispo de Yucatán, México a 18 de enero de 1725», «Representación al rey del cabildo de Mérida contra el sínodo del obispo Gómez de Parada, Mérida a 18 de septiembre de 1722, en: J. GómEz DE PARADA, op. cit. 349-354.

Hispania Sacra, LXIII

128, julio-diciembre 2011, 469-499, ISSN: 0018-215-X 
usura por comprar los géneros con anticipación a bajos precios o vender mulas a muy altos ${ }^{85}$ explicando que en nada se perjudicaba a los indios y todos salían ganando. El procurador hacia un cálculo diferente al obispo, sobre el monto de las obvenciones en los curatos yucatecos, concluyendo que ganaban más de lo que la mitra expresaba. ${ }^{86}$

En febrero de 1723, los regidores de Mérida escribieron a la audiencia en contra de la resolución sinodal que permitía al clero parroquial contratar a los indios para trabajar en sus cultivos y comercializar los géneros que recibían de obvenciones. ${ }^{87}$ Puesto que los curas disponían de mano de obra barata o gratuita, los precios de sus productos eran menores. ${ }^{88}$ Aunque en el sínodo se daba libertad a los indios de pagar obvenciones en especie o en dinero, acusaban al obispo de que en catedral les había ordenado pagar sólo en especie. Se ve claramente su temor de que el clero parroquial llegase a dominar el comercio interno de Yucatán.

Por su parte, el gobernador magnificó los perjuicios de la suspensión de servicios e incluso difundió que los indios se iban a rebelar. Según el mismo, los indios ya sólo obedecían a los eclesiásticos, quienes tenían un poder ilimitado, ${ }^{89}$ los repartimientos de algodón y cera no se podían ya cobrar porque los in-

85 Libro quinto, título quinto, párrafo cuarto: «...conforme a las reglas de la buena teología, declaramos que el comprar mucho más barato o en mucho menos dl precio ínfimo justo que la cosa vale, precisamente por razón de la dilación de la entrega de la cosa, es usura...», en: J. GómEz DE PARADA, op. cit. 202.

86 «Representación del procurador de la provincia contra la aprobación del sínodo celebrado por el obispo de Yucatán, México a 18 de enero de 1725», «Representación al rey del cabildo de Mérida contra el sínodo del obispo Gómez de Parada, Mérida a 18 de septiembre de 1722, en: J. Gómez DE PARADA, op. cit. 354: «... aseverando los del pueblo de San Pedro y San Pablo de Teabo (con quienes en la sustancia concuerdan los demás) que todas las limosnas que pagan a los padres en el discurso del año de patíes, cera, maíz, frijoles, chile, miel gallinas, onza de hilo que dan mulsiles y todo lo demás que pagan les cuesta grandísimo trabajo buscarlo [...] que si lo pagaran a reales de plata recibirían mucho bien porque cuando falta el maíz y los demás expresado en la certificación venden su ropa yendo a buscar lo que han de entregar y comprándolo en diferentes pueblos...»

87 «Representación ante la Audiencia de México del cabildo de Mérida y abogado de los naturales, sobre los perjuicios que se siguen del sínodo realizado por el obispo Gómez de Parada, México a 6 de febrero de 1723», en: J. GÓMEZ DE PARADA, op. cit. 299.

${ }^{88}$ Ibidem 300: «... de ello nace el que el comercio todo esté refundido entre los eclesiásticos. Si con prohibición y temor del castigo se arrastraban mucha parte del comercio, con permisión y facultad de mixturarse en el mayor trato que hay en aquella provincia, como es el de las milpas y tejidos, ¿qué harán?»

89 «Informe del gobernador al rey sobre los perjuicios de la comisión del obispo, pidiendo su restitución en el cargo. Mérida, 12 de febrero de 1724, en: J. Gómez DE PARADA, op. cit. 164: «...hallé en el pueblo de Hunucmá puesta una picota a la puerta del ministro doctrinero de aquel pueblo donde hacía azotar a los indios como pudiera ejecutarlo la real justicia... por las justicias del pueblo de Yaxcabá consta la autoridad de su beneficiado sobre los indios, haciendo que no respeten a su cacique y que los indios no acudan a las obligaciones del pueblo...» 
dios no obedecían. Los repartimientos de géneros eran indispensables a los gobernadores debido a los gastos de gobierno, como la visita de los puertos y las costas. Por todo ello, Cortayre pedía la restitución de sus funciones de gobierno para recomponer la provincia.

En el punto más álgido del enfrentamiento, el gobernador escribió al mismo obispo reprochándole varias cosas: los bajos salarios que la Iglesia pagaba a los indios, que tiempo atrás el prelado había aprobado los repartimientos, e incluso invirtió más de 8000 pesos en ellos, y que la comisión del obispo no implicaba hacer a sus clérigos ministros de la justicia real..$^{90}$ Algo similar escribió al virrey: «...los clérigos sacerdotes corren toda la tierra hechos jueces reales y ministros de justicia, haciendo prisiones de seculares y haciendo declaren con amenazas de censuras...»91

Una dura respuesta de Gómez de Parada no se hizo esperar: destituyó el gobernador, sustituyéndole él mismo, y aun más, lo excomulgó. ${ }^{92}$ Según el procurador, para tener justificada la destitución del gobernador, el obispo ordenó a varios clérigos y curas levantar testimoniales en su contra, siendo algo que no le daba derecho la comisión. El golpe fue tan duro, que el mismo gobernador pidió al prelado que le quitara la excomunión. ${ }^{93}$ Lo que más había dolido a los poderosos de Yucatán, sin duda, había sido el intento del prelado por suprimir los repartimientos de mercancías en los pueblos de indios, negocio que encabezada el gobernador. ${ }^{94}$

La fuerte oposición de las elites y el clero a las reformas del obispo tuvo su efecto en Madrid, a tal grado de ordenarle suspender su continuación y pedirle informes puntuales sobre la situación imperante. En noviembre de 1723, Gómez de Parada informó que había detenido los cambios y que ya tenía en su poder los informes de los curas sobre los servicios que se daban a españoles y mestizos en sus distritos. Luego que frenó la reforma, ordenó a los pueblos que siguieran enviando indios como antes.

El gobernador, por su parte, instauró nuevamente los servicios y restituyó los repartimientos de cera y patíes, acabando con cualquier libertad ganada por

\footnotetext{
90 «Carta del gobernador al obispo. Campeche, 27 de junio de 1724», en: G. Solís RoBLEDA, editora, Contra viento y marea...181.

91 «Carta del gobernador al virrey marqués de Casafuerte. Campeche, 7 de julio de 1724», en: G. Solís Robleda, editora, Contra viento y marea ...183.

92 «Petición del procurador de Yucatán a la audiencia para que evite la destitución y excomunión del gobernador. México, 9 de agosto de 1724», en: G. Solís RobledA, editora, Contra viento y marea..., 187-191.

93 «Petición del gobernador al obispo para que le quite de la excomunión, Mérida, 22 de agosto de 1724», en: G. Solís RoBledA, editora, Contra viento y marea....193.

${ }^{94}$ Según averiguaciones del obispo, el gobernador había repartido un total de 77816 patíes y 482 arrobas de cera en dos años y medio.
} 
los indios. En especial, el obispo denunció el papel de los caciques en todo esto: «Porque todo esto y todas las acciones de una vida humana han de estar sujetas al imperio y potestad del cacique rudo, bárbaro, tímido y mal cristiano que no tiene vigor para negarse al que le domina, ni entendimiento ni recurso, ni más que la facultad de ejecutar a ciegas en los mismos indios lo que se le manda...»95 Gómez de Parada pedía al rey una definición puntual: o le quitaba la comisión y se desentendía del asunto, o bien, se la confirmaba del todo, dándole los auxilios necesarios.

En octubre de 1724 la real audiencia de México ordenó al obispo suspender las medidas contra el gobernador; mientras que el monarca, en cédula de 22 de junio de 1725, suspendió la comisión al obispo. En marzo de 1726, Gómez de Parada avisó al rey que había suspendido definitivamente su comisión: «...en que tuve presente no poder conseguir fruto alguno teniendo -como tenía- a vuestra real audiencia contraria a dicha comisión e inclinada a satisfacer al deseo común de españoles...»96

En lo que respecta a la diócesis, Gómez de Parada decidió suspender la aplicación del arancel. ${ }^{97}$ No obstante, en 1740 el obispo Francisco Matos Coronado logró por fin una cédula que así lo ordenó, arancel que siguió vigente hasta el fin de la colonia. El colofón de la empresa de Gómez de Parada fue su designación como nuevo obispo de Guatemala en agosto de 1727; al año siguiente, el obispo dio las gracias y avisó que ya estaba en camino a su nuevo destino: «...vuestra real benignidad fue servido de concederme el consuelo que sumamente deseaba para mi quietud de sacarme del obispado de Yucatán y de mi continuado desasosiego... ${ }^{98}$ El status quo de Yucatán se había impuesto por entonces a la radicalidad de un obispo adelantado a su tiempo.

\section{REFLEXIONES FINALES}

El análisis del manejo de los derechos parroquiales es una ventana privilegiada para comparar, por un lado, la situación económica de los curatos, y por

\footnotetext{
95 «Carta del obispo al rey informando sobre el cese de la reforma del servicio personal. Mérida, 3 de noviembre de 1723», en: G. Solís RobledA (editora), Contra viento y marea..., 154-160.

96 «Carta del obispo al rey sobre haber suspendido la ejecución de su comisión. Mérida, 13 de marzo de 1726», en: G. Solís RoBLEDA, editora, Contra viento y marea...200-201.

97 A. Rocher Salas, op . cit. 305: «Años después, los obispos Francisco de Matos e Ignacio Padilla lograrían que entraran en vigor algunos de sus artículos relacionados con los derechos parroquiales. Sin embargo, la gran mayoría, incluyendo aquellos que repercutían en el funcionamiento franciscano, fue desechada».

98 G. Solís RobledA, editora, Contra viento y marea... 201. El obispo da gracias al rey por su nombramiento como obispo de Guatemala, 20 de septiembre de 1728.
} 
el otro, ahondar en las relaciones económicas y políticas que se establecían entre el clero parroquial, los pueblos y los poderes provinciales. En los estudios que hay sobre obvenciones parroquiales normalmente se toma en cuenta sólo a los curas y a los fieles, pero el expuesto aquí demuestra que podían estar involucrados otros sectores de la sociedad con amplios intereses en el trabajo indígena. De esa forma, para entender mejor la conformación y dinámica de las rentas parroquiales es menester no perder de vista, en primer lugar, el conjunto de exacciones de los pueblos que conforman una parroquia y, en segundo lugar, a los demás actores locales con autoridad e interés en el asunto. Pero aun más, tales exacciones podían ser invertidas en el más amplio sistema de repartimientos de mercancías y de dinero que involucraba al resto de los grupos de poder.

Los afanes del obispo Gómez de Parada en Yucatán no fueron aislados ni producto sólo de su iniciativa personal, sino que formaron parte de una tendencia de la nueva monarquía para cambiar el estado de cosas en la Iglesia indiana, cuya esencia era lograr una mayor sujeción del clero y la siempre deseada reforma de las costumbres. Al llegar noticias a Madrid sobre la opresión de los indios y la participación del clero en ello, no se dudó en pedirle al nuevo obispo su involucramiento total para resolverlo, para lo cual incluso se le dotó de poderes especiales. Esto nos indica que Felipe V dio al prelado, al principio, todo su apoyo.

Gómez de Parada, optimista, usó ampliamente de su jurisdicción y de su comisión especial para intentar modificar en algunos meses lo que había llevado dos siglos establecer. Sin duda, confiaba mucho en el poder del nuevo monarca y en su propia capacidad de acción. La empresa que emprendió era muy ambiciosa, pues si, por un lado, quiso reformar su Iglesia, incluyendo a ambos cleros, por el otro, intentó la reforma del sistema de trabajo indígena que descansaba en los servicios personales forzosos y los repartimientos de mercancías y dinero.

Inmerso en tal dinámica, entre 1722 y 1723 se convirtió en el personaje más poderoso y controvertido de Yucatán que incluso excomulgó al gobernador y le quitó del cargo, algo pocas veces visto. Pero el trasfondo del asunto fue, en realidad, lo que más preocupó a las elites de poder establecidas de la región: el cambio de régimen de apropiación de los excedentes indígenas, que pugnaba por establecer la libertad de trabajo y de comercio de los pueblos, con lo cual quedarían derogados el trabajo forzoso y los repartimientos que encabezaba el gobernador y favorecía a funcionarios, encomenderos, milicia, comerciantes y clero parroquial.

Sobre este último, la reforma pretendida por el obispo comprendió de manera especial el establecimiento de un arancel general para el pago de las obvenciones y terminar con el uso indiscriminado que los curas hacían de la mano de 
obra de sus feligreses para sus propios intereses. Gómez de Parada comprendió muy pronto que, en los curatos y doctrinas de su diócesis, no había una frontera clara entre el pago de los derechos parroquiales y la prestación de servicios personales al cura en su calidad de patrón; en otras palabras, bajo el manto de las obvenciones se escondían todo tipo de exacciones extraordinarias, ya fuera de trabajo o de géneros, por parte de los curas y doctrineros.

La exclusión de los curas del reparto del diezmo conllevó a una vinculación directa de éstos con la actividad productiva de los pueblos: puesto que la mayor parte de los ingresos de cada parroquia salía de los mismos pueblos, para los primeros fue básico lograr convenios que les aseguraran una renta segura y excedentes tales que permitieran a los franciscanos seguir teniendo una provincia sustentable, y a los clérigos desarrollar negocios propios y formar un patrimonio.

Para lograrlo, todos ellos dependían de la capacidad productiva de los pueblos, el entendimiento con sus gobernantes y que el pago de las obvenciones incluyera preferentemente géneros y servicios personales, lo cual les facilitaba su participación en el mercado y en los repartimientos de mercancías. Ante ello, la apuesta del obispo fue convencer a los curas que sus obligaciones con la administración espiritual eran primero, que había que desligar de sus intereses particulares los derechos parroquiales, que todo servicio personal de los feligreses debía ser independiente del pago de las obvenciones y pagado de acuerdo a un salario, y, finalmente, que ellos eran ministros diocesanos y como tal debían apoyar las reformas impulsadas desde la mitra y sancionadas por Madrid.

Sin embargo, el clero de Yucatán prefirió apoyar el status quo y se unió contra las reformas, argumentando que los cambios, más que beneficiar a la provincia, la perjudicaban en general. La tensión política que se produjo entonces puso a prueba al mismo gobierno de Felipe $\mathrm{V}$, pues si en un principio dio poderes especiales al obispo Gómez considerando que era la «punta de lanza» para lograr cambios sustanciales en Yucatán, ante el descontento generalizado la corona dio marcha atrás.

Los hechos mostraron al rey que la reivindicación indígena y la reforma del clero impulsadas por su obispo podían tener un alto costo político en relación con las elites de poder dominantes. Si bien la nueva monarquía buscaba consolidar su poder en Indias y demostrar su fuerza, ello no implicaba ocasionar una oposición tal que pusiera en peligro las lealtades de los colonos poderosos.

La suspensión de las reformas en 1724 no significaron, por otro lado, una claudicación de la corona o de la Iglesia secular en tales asuntos, sino más bien un replanteamiento de la estrategia a seguir, pues en la década de 1740 comenzó a discutirse con toda seriedad la posibilidad de decretar una secularización general de las doctrinas de los religiosos, como el paso imprescindible para imponer un nuevo ordenamiento eclesiástico en Indias. 